\title{
探析城市集中供暖的节能技术途径
}

\author{
连荭毅 \\ 新疆峻特设计工程有限公司 III \\ DOI:10.32629/btr.v3i8.3341
}

\begin{abstract}
[摘 要] 在城市发展中,供暖问题的作用非常重要,目前,过对供暖提出了节能减排的要求,作为相关的从 业人员应研究供暖的节能技术, 确保供暖可以实现节能减排, 实现环境保护并促进社会发展。本文就城市 集中供暖的节能技术进行分析,希望为促进城市技能及社会可持续发展提供参考。
\end{abstract}

[关键词] 城市; 集中供暖; 节能技术

中图分类号: S210.4 文献标识码: A

近几年, 随着经济的不断发展, 能源 问题成为了全世界人民关注的焦点, 人 们的节能意识也日益增强, 各行各业都 在积极的研发及应用节能技术。我国自 改革开放以来, 对能源的需求与日俱增, 具有关数据显示, 我国已成为了能源消 耗的第二大国。建筑能耗占我国能耗很 大比例, 集中供暖可以大大提高供暖质 量、减少污染、降低能源的浪费, 目前我 国北方均采用集中供暖。然而从整体来 看, 我国城市集中供暖系统的节能效果 欠佳, 建筑围护结构气密性、保温隔热性 能差。国家为了提高能源的利用率, 编制 了居住建筑与公共建筑节能设计标准, 通过改善设备和供暖系统的利用率, 以 及提高建筑围护结构保温隔热性能, 这 个标准在符合我国的国情的基础上实现 了节能 $50 \%$ 以上的良好效果。

\section{1 城市集中供暖节能技术分类}

1. 1 太阳能辅助加热技术

随着能源危机和环境污染的恶化, 太阳能作为节能、环保、低成本的绿色 能源, 已得到越来越多的应用。太阳能技 术就是利用太阳的能力与光为家庭、商 业或工业提供热量、照明、热水等, 太阳 能中央热水系统以太阳能为主要能源, 与电能或其它能源配套使用, 稳定性好, 自动化程度高。无烟气排放, 降低了热水 成本, 节省了大量能源。更具不同用户的 实际情况为用户从方案设计、设备选型 到工程施工, 进行专业化一站式服务。

\section{2 气候补偿技术}

根据气候的变化, 调节室内温度, 保证供热质量, 使能源消耗得到有效降 低, 达到节能的目的。气候补偿调节技 术, 根据用户设定不同的室内温度要求, 根据气候的变化和四次调节关系曲线 调整供回水温度, 当室外温度升高时, 供水的温度降低; 当室外温度降低时, 供水温度升高, 此过程依据热负荷的需 求自动调整, 使室内温度与室外温度保 持基本恒定, 保证供热质量, 有效降低 能源消耗。气候补偿系统由控制器、电 动调节威、室外温度传感器、供回水温 度传感器等, 加之相应的控制软件组成, 该系统中的四次供热调节曲线属于国内 首创, 价值更合理, 控制更精确, 节能效 果更为显著。

\section{3 锅炉运行管理的有效方法 \\ 1.3.1 锅炉除焦剂的应用}

链条锅炉在正常使用过程中, 由于 其除焦剂都是在特定的条件下进行使用， 所以不会产生相应的物理反应, 因此, 导 致链条锅炉系统在正常的使用过程中, 除焦剂的颗粒不会与杂质产生化学反应 或是物理反应, 这样能够解决锅炉中内 部存在的主要问题, 同时, 还能让锅炉得 到较好的运行条件, 提升其运行效果。减 少对环境污染的同时, 还能提高自身的 工作效率。其主要效果可以通过以下几 点来体现:（1）链条锅炉使用的过程中, 除焦剂能够针对锅炉内部的杂质进行调
整, 将存在的杂质进行高速溶解。(2) 在 除渣的过程中, 会生成较多的气体, 其会 对周围环境产生较大的影响, 为此在使 用锅炉的过程中, 应该根据实际需求来 控制量的使用, 从而减少其燃烧所产生 的烟气。(3) 针对锅炉内部产生的杂质进 行处理的过程中, 除焦剂还有较好的促 燃作用, 这样使得锅炉设备燃烧效果得 到较好的帮助, 而且不会对其内部产生 其他方面影响, 不会减少其使用寿命, 同 时有较好的节能效果。

如果链条锅炉在使用的过程中, 没 有运用除焦剂, 则锅炉内部一些杂质就 会比较突显, 在内部会形成一个黑色的 结构, 这样会让锅炉装置在正常使用中 会受到影响, 其自身的工作效率会受到 较大的影响, 在长时间这样的情况运用, 会给设备造成大幅度的破坏, 很容易产 生损坏现象, 而且还很容易产生安全问 题。因此, 在链条锅炉运用的过程中应该 根据情况使用材料进行调整, 从而将其 真正意义发挥, 使得其设备得到保障, 减 少给锅炉造成其他影响, 从而保证我国 工业的有效发展。

\subsection{2采取分层燃烧技术}

燃烧分层燃烧设备由笁分机和给煤 机两大部分组成。给煤机的设备需要不 同的内容来构成, 从而实现有效的组成。 并实现转动, 其设备在运行的过程中不 需要电能源的支持。调节挡板会给煤机 造成影响, 给煤机传送出的燃煤进入炉 
排时, 其会自动进行篮选, 同时, 与炉内 之间生成一种特殊的形式, 在燃煤的过 程中进行选择, 通常情况会根据颗粒形 状来进行选择, 并将其调整在炉内前方, 而颗粒较小的部分会存落于缝隙中。在 当前炉内不断运转的过程中, 形状较大 的从煤体落到煤层底部, 由细变粗, 从上 到下均匀的形成煤堆。这种形式有利于 增加上层的空气流通量, 同时, 还能减少 下层存在的通风问题, 从而保留有效的 燃烧缝隙。

\section{2 应对城市集中供暖的节能 措施}

2. 1 提高保温、管网输送效率

通常, 外部管道网络的运输热效率 应超过 $90 \%$ 。这一过程的有效落实涉及到 设计过程中要合理选择高质量的绝缘和 节能材料, 同时加强维护和管理, 以避免 诸如损坏和水浸之类的问题。为了提高 热量的有效供给和管道网络的传输效率, 必须从以下几点进行改进: (1) 为埋入地 下水的热网络的主管道和副管道铺设和 装备外部管道网络时, 可能会发生泄漏。 可以使用泡沫橡胶作为处理的密封材料, 以使地下水不会渗入较小的内部汲水管 或壳体壁。此外, 还可以对加热网络中所 有开放式补偿器芯进行隔热。(2)为了提 高通过管网的热量节省和运输效率, 还
必须确定热管网的绝热层的厚度。确定 厚度时, 必须遵守国家标准“设备和管道 隔热设计指南”中的厚度, 并确定管道保 温层厚度的计算公式。

2. 2 合理设计, 引进先进技术

关于集中供热系统的供热和节能问 题, 我们首先必须在计划阶段进行检查: 在每个供热阶段的计划工作中, 我们可 以利用国际基本计划思想来计划供热点 和铺设管道的位置。以城市当地条件 (例 如温度和地理条件) 灵活地设计和处理 供热项目的系统建设。为了提高整体性 能, 开发团队之间需要充分沟通并相互 沟通以改善协作。在开展实际工作时, 必须做好节约能源和减少排放的工作， 并充分利用人力和物力。同时, 有必要促 进先进技术和方法的使用, 以通过合理 的节能技术应用来改进供暖工作的节能 降耗效果。

\section{3 合理选择供暖热负荷指标}

在城市集中供热系统设计的早期, 通常需要正确评估建筑物的热负荷。在 计算单个建筑物的热负荷时, 可以使用 公式 $Q=q F \times A$ 。供暖的热负指数需要相 关人员与实际情况相结合之后再确定, 室内和室外供暖的估计温度及建筑物 的高度。供暖系统的供热效果受到多方 面因素的影响, 因而相关人员需要根据
已建成房屋的测量数据来建设供暖系 统的设施。

\section{3 结语}

在城市集中供暖过程当中, 应当加 强对供暖设备的改良, 改进供暖系统当 中的能源消耗结构, 加强对于节能技术 的开发与利用, 确保管网传输过程当中 能源的高效转化与利用, 促进社会向着 能源节约与科学环保的方向发展, 推进 城市的可持续发展。

\section{[参考文献]}

[1]王波,赵振华.集中供热采暖节能 的必要性及节能设计探析[J]。住宅产 业,2018,(10):61-63.

[2]牛亚萍.城市集中供暖的节能技术途 径分析[J].山西建筑,2018,44(10):187-188.

[3] 徐义娜.城市集中供暖的节能技 术途径分析与研究 [J]. 科学技术创 新,2018,(05):138-139.

[4]尹富強.城市集中供暖的节能 技术途径分析与研究 [J]. 山西建筑, 2017,43(30):183-184.

[5]徐义娜.城市集中供暖的节能 技术途径分析与研究[J]. 黑龙江科技信 息,2018,(5):138-139.

[6]谷志涛.城市集中供暖的节能技术 途径分析与研究[J].居舍,2019,(10):51. 